\title{
The Cultural Contradictions of Philanthrocapitalism
}

\section{David Bosworth}

Published online: 28 July 2011

(C) Springer Science+Business Media, LLC 2011

Every excess causes a defect; every defect an excess. Ralph Waldo Emerson

It is appropriate that Robin Rogers begins her informative essay on the state of philanthrocapitalism with a very large number - the 600 billion dollars in charitable donations promised by 40 über -rich Americans through the Giving Pledge; for both the current corporate culture whose private wealth feeds contemporary philanthropy and Bill Gates, the public figure who features most prominently in any account of the field, are deeply invested in the philosophical presumption that material quantity (as measured by goods produced, profits made, gross efficiencies achieved, effective methods scaled) can reliably generate social quality. Because overall and in the end, more engenders better, the business of government (and most everything else, including scholarship, medicine, and public education) should be conducted in the manner of a corporate business - that is, by and for "the numbers."

This doctrine, which I have been calling quantiphilia, has so saturated American culture that, like any commonsense belief, it now appears to be immune to effective critique. Despite a near total collapse of the global economy as generated by the egregious incompetence of corporate finance, the core notions of quantiphilia, including the idealization of corporate techniques, still dominate the position papers of our policy elite, and with our final assessment of value in all things now commonly defined as "the bottom line," its logic has also succeeded in "monetizing" our everyday speech. The

D. Bosworth $(\bowtie)$

University of Washington,

Box 35-4330, Seattle, WA 98195, USA

e-mail: davidbos@u.washington.edu credo that more must equal better is crudely manifest in the super-sized meals that weigh down the trays in our fast-food restaurants, and in the super-sized cars and homes (faux chateaux) that were popular until the economy collapsed. Most relevant here, that credo can be counted in the super-sized pay days of our corporate CEOs and venture capitalists, whose astounding income is the source of the 600 billion pledged.

There is, however, an alternative way of assessing social health and pursuing social quality, one that values harmony over sheer quantity, the complementary actions of homeostasis over the aggressive mechanisms of linear progress. This was the broader theme of that most American of philosophers, Ralph Waldo Emerson, in his essay "Compensation," from which my epigraph has been taken. His assertion there that "every excess causes a defect; every defect an excess" highlights the irony that haunts recent assertions that philanthrocapitalism, as distinct from both democratic government and more traditional forms of philanthropy, can solve our social ills. For the excess, and so defect, most obvious in American society today is the severity of our economic inequality, which has dramatically increased over the last 40 years as the agenda of quantiphilia has taken hold. In 1970, the wealthiest $1 \%$ of Americans received 9.7\% of the national income; now that number has surged to $23.7 \%$, and the top one-tenth of that one percent (the targets of the Giving Pledge) receive 12.3\%. America's latest score of 45 on the Gini Index, which measures disparities in income distribution, is conspicuously worse than all our Western allies. These statistics matter because nations that suffer such economic disparities are more susceptible to the very social ills - cyclical poverty, early mortality, illegitimate births, poor test scores - that philanthrocapitalism now aims to cure. 
In one sense, of course, the Giving Pledge is heeding Emerson's principle of compensation, striving to restore social balance through self-conscious acts of generous giving. As the authors of that pledge, Bill Gates and Warren Buffet appear to be following an age-old moral imperative, one concisely expressed by Simone Weil: "If we know in what way society is unbalanced, we must do what we can to add weight to the lighter scale (Weil 1963)." What differentiates today's efforts from earlier ones is the ideological presumption that the same techniques, management style, and value system that helped to generate the excessive income that is funding the pledge can also correct the social defects historically associated with income inequality.

No individual can fully represent an entire movement, but as the wealthiest man in America and the most proactive of today's philanthrocapitalists, Bill Gates comes close. A preliminary examination of the man's stature, intentions, characteristic strategies, past accomplishments and current failures illustrates why a democratic citizenry might doubt this movement's redemptive claims.

\section{The Royal Status of Today's Philanthrocapitalist}

\section{Businessmen and businesses are best placed to save the world. \\ Bill Gates, speaking at Davos}

Although, born in revolt against a monarchy, America lacks an official royalty, our nation still possesses the same social and psychological needs that royalty has traditionally fulfilled. All complex societies require public figures that, drawing collective admiration, unify their otherwise diverse populations through symbolizing an underlying set of common aspirations. In a nation whose original intention was to replace the British aristocracy with a homegrown meritocracy, our high-achieving athletes, actors, musicians, and entrepreneurs are now elevated into a stratosphere of acclaim to fulfill that role. The fascination that accompanies their royal status, however, also tends to suspend effective evaluation, and their achievements in one field can lend them an authority unmerited in others.

I am a long-time resident of Seattle, moving here in the year that Microsoft released the first version of its Windows franchise, and so I was an early witness to the royal spell that Gates can cast on public opinion. Melinda Gates's first pregnancy was front page news here; charter boats coursing the inland waterways that both bound and bisect Seattle, include glimpses of the family's lakefront estate on their tours; and in a local newspaper profile in the 1990s, Gates and his leading technology officer were actually compared to Plato and Aristotle. Such profiles are commonly puff pieces, of course, but however hyperbolic the praise, that gross equation of corporate success with philosophical wisdom did reflect the nation's awed admiration of the man at a time when the release of Windows 95 was greeted as if it were a blockbuster movie or, yes, a royal marriage. More to the point here, that equation helps explain the political authority that Gates and his allies are now gaining to direct public policy on his pet issues of global health and national education reform, absent the usual requirement of holding public office.

It is important to reflect on the true sources of this stature and the values they represent. In contrast to previous corporate icons like Henry Ford and Walt Disney, who, although equally fierce managers and competitors, were also masters at projecting a folksy, feel-good image of themselves and so, too, of the corporations that bore their names, Bill Gates - to his credit, perhaps - is not a natural salesman. (Case in point: he wanted to call their new graphical operating system Interface Manager and had to be convinced by his marketing director that Windows would be more appealing to consumers.) Indeed, despite the casual dress he prefers, Gates has always radiated a certain arrogance, the intellectual elitism of a technocrat who does not suffer critics, usually equated with fools, gladly. But what would be a fatal character flaw in any democratic politician has proven to be irrelevant in the case of the successful CEO. By dominating the race to market the next truly revolutionary technological advance, Gates made himself the wealthiest man in the world, and in a nation of Yankee engineers converted to quantiphilia, those numbers do matter. Where more is naturally presumed to be better, the most must mean the best. As the even less personable Mark Zuckerberg now appears to be doing, Gates became the secular hero of his generation by marrying technological how-to with managerial can-do to win the numbers game and score the most bucks.

That this hero had yet to perform any good deeds in the charitable sense, that his original status was rooted in sheer self-interest rather than the self-sacrifice normally associated with the heroic figure, were by then familiar ironies on the American scene. In a patterned performance first established by some of the plutocrats of the Gilded Age, Andrew Carnegie most prominently, a second act of material generosity would redeem the moral ambiguities of the first. Conspicuous philanthropy would compensate for cut-throat avidity. And once the ruling motive had flipped from acquisition to donation, it was simply presumed that the managerial success of the corporate magnate would reliably convert to the public good. This was the difference, after all, between a royal status bequeathed through an aristocracy and one achieved within a meritocracy. Having been tested in the competitive fires of the marketplace, our entrepreneurial billionaires had earned 
their status, and with their Machiavellian efficiencies now redirected to civic virtue, "the bottom line" of social improvement would surely spike.

Yes, the ability to project a folksy self-image might help the cause, but like those brusque benefactors in Dickens' novels, the philanthrocapitalist did not have to make-nice to do good. Quantifiable competence not vaporous charm was the trait that mattered most. And in the case of Bill Gates, who was better qualified to rescue public education than the broadly acknowledged smartest-man-in-the-room? The original Plato had founded the Academy; our latter-day version would rescue it from ruin.

\section{Monopolizing the Market of Ideas}

Unfortunately, this pretty narrative, wherein the technocratic billionaire naturally becomes our cultural savior, does not hold up to scrutiny. The ideological presumption is that the donor's philanthropic projects, like the commercial products that made him wealthy, have been rigorously tested in a Darwinian marketplace where only the best ideas can survive. But whether or not this is even true of his corporate ventures (see below), it does not apply in practical fact to his philanthropic ones whose funding is dependent on the donor's will alone. As a hands-on philanthrocapitalist, Gates insists that the initiatives of the Bill and Melinda Gates Foundation (BMGF) are rooted in the objective analysis of the best experts in each field, but in most cases, the evaluators of those initiatives have been hired by either the foundation itself or its subsidiaries. As courtiers were given to flatter the king, today's policy analysts have a vested interested in pleasing their patrons. In the words of Frederick Hess, director of education policy at the American Enterprise Institute, "academics, activists, and the policy community live in a world where philanthropists are royalty" whose disapproval can result in the practical equivalent of professional defunding (Hess 2005). This is especially true with the BMGF which, like its founder in business, aims to dominate every field it enters.

In 2008, the New York Times reported that the chief of the malaria program for the World Health Organization, Dr. Arata Kochi, had "complained that the growing dominance of malaria research by the BMGF risks stifling diversity of views among scientists and wiping out the health agency's policy-making function (McNeil 2008)." When the same foundation chose to promote smaller American schools from 2000-2008, it did so with a vengeance to similar effect. "Gates funding was so large and widespread," writes education advocate Michael Klonsky, "it seemed for a time as if every initiative in the small-schools and charter world was being underwritten by the foundation. If you wanted to start a school, hold a meeting, organize a conference, or write an article in an education journal, you had to consider Gates (Klonsky 2011).”

Nor, with a few notable exceptions, can we count on the mainstream press to fulfill its usual watchdog role. According to Hess, when Gates gave a major speech on public education to the nation's governors in 2005, of the 44 newspaper stories that covered it, "not one questioned his assessment or critiqued his recommendations." A subsequent analysis of the press coverage of all the major foundations who support public education reform found that the ratio of positive to negative stories was 13 to $1 .{ }^{1}$ The reasons for this arrant favoritism include the usual American obsequiousness to the royalty of the super wealthy, a general sense that it is rude to criticize largescale acts of generosity, and the press's dependence on the same policy experts who have been co-opted by the foundations in question.

Thanks, ironically, to the corporate incompetence that triggered the Great Recession, this monopolizing of public opinion by corporately earned money is only likely to get worse. As government funding for medical and social research shrinks, the experts' dependence on foundation money soars, and, desperate for funds, local school districts cannot easily resist the national reform initiatives now be dictating by billionaire donors with no local connections.

Meanwhile, as the old economic model for journalism collapses, the BMGF has stepped in there as well. A recent (and rare) investigative report by the Seattle Times revealed that the foundation had contributed over 69 million dollars since 2002 to news organizations and journalism schools "to promote coverage of its central issues: global health, development, and education (Doughton and Heim 2011)." The media outlets supported include PBS's News Hour and Frontline, NPR, ABC, and The Guardian in England. Although these recipients routinely deny being directly influenced by the foundation, their very dependence on the money places them in the same subservient position as the policy experts who have been paid to evaluate the foundation's programs. On the political front, it is illegal for charitable organizations to contribute directly to individual candidates, but that did not stop Gates and Eli Broad of the Broad Foundation from spending 60 million dollars on a public information campaign before the 2008 election, with the aim of influencing both parties to adopt their shared agenda for education reform.

Robin Rogers argues for the separation of philanthrocapitalism from public policy-making, but on the subjects that matter most to Gates, that battle appears to have been lost. With their "partners" in policy, journalism, and both local and national politics secured, the BMGF and its primary allies on school reform, the Broad Foundation and the

\footnotetext{
$\overline{{ }^{1} \text { Hess, pp. } 10-12 .}$
} 
Walton Family Foundation (the Walmart clan), have now leveraged a relatively tiny investment - less than one percent of the monies spent each year on public education - into a commanding position. The public still pays most of the bills, but it is the philanthrocapitalist who, increasingly, sets the agenda.

The climax of this leveraged takeover occurred with Obama's selection of Arne Duncan to lead the Department of Education (DOE). As the "CEO" of Chicago's troubled public schools (note the conversion to corporate terminology characteristic of quantiphilia), Duncan had already implemented a reform program, Renaissance 2010 (Ren10), that was based on the BMGF's how-to guide, The Turnaround Challenge, and supported by 90 million dollars of the foundation's money. At the DOE Duncan has championed the same guide as the "bible" of reform, and integrated its goals - charter schools, performance-based pay for teachers, national testing standards, and the power to effect a "turnaround" by firing the staff of lowperforming schools - into his Race to the Top initiative, which has used federal money from the "stimulus package" as an incentive to state governments to conform to the same agenda. That temptation was then sweetened by the BMGF which offered both money and professional guidance to the states that were applying, and with the federal government now joining Gates's other paid partners in policy analysis and the media, his domination in the field of school reform is nearly complete.

None of this should seem surprising. "Nature [may] hate monopolies," as Emerson also wrote in "Compensation," but capitalism certainly does not. Especially in eras of technological change, only an aggressive application of antitrust regulations will prevent a few corporations from acquiring a stranglehold on whole new segments of our political economy. Just as Carnegie's U.S. Steel and John D. Rockefeller's Standard Oil monopolized the then new industries of steel and petroleum production, Microsoft has monopolized the PC software industry. Gates made his enormous fortune less by product innovation than by cleverly and ruthlessly dominating his industry's distribution system — that is, by eliminating the very competition that is supposed to spur technological improvement; and in the new era of hands-on giving, he has now been applying the same tactics to his second career as a philanthrocapitalist.

Having installed Windows in some $90 \%$ of today's PCs, Gates is on the verge now of defining the default "operating system" for public education as well. The fate imposed on most independent software developers and PC manufacturers in the 1990s is now being faced by professional educators: to enter the game at all, they will have to play by the rules established by the Gates, Broad and Walton foundations, as defined in their grant initiatives, training conferences, and how-to guides, and as enforced by their latter-day minions in government like Arne Duncan. Hewing to the quantiphilia characteristic of mass manufacturing, those rules will insist on running our schools by and for the numbers, overvaluing abstract testing and scaling their favorite strategies to standardize educational "production" from coast to coast. The practical effect will be the technocratic elimination of local control over public schools - all pursued, of course, "with the best of intentions" and without any real concern as to the impact on democratic initiative.

Given the authors of such a "turnaround" agenda, these results too should not prove shocking. Total authority, after all, is what monopolists usually seek, and for technocratic managers, rote measures of productivity routinely replace the less quantifiable standards of effective citizenship. The usurpation of local control has been a longstanding theme of our corporate economy, evident, for example, in the replacement of the family farm by agribusiness. And whether one believes such a result is desirable, it is certainly logical that the same vested owners whose bigbox Walmarts have been displacing local retailers are now funding, through their tax-sheltered foundation, an equivalent disempowerment of local educators.

\section{Grade Inflation: the Philanthromonopolist's Immunity to Failure}

The Royals go on and on, that's what they do. They are not sackable.

- an unnamed cabinet officer, commenting on the embarrassing behavior of Prince Andrew

So what?, the editors of Forbes and the attendees of the World Economic Forum at Davos are likely to respond. In a global economy, we cannot afford a nostalgic allegiance to the archaic virtues of the local school board. In our digital era, the price of progress is perpetual change; education must lead the way; and with a GPS for a mind and his eyes laser-locked on the bottom line, the high-tech businessman "is best placed to save the world" by designing an education "delivery system" for the 21 st century.

No one would deny that we are being changed and challenged by our new technologies. But do the members of the Good Club really Know Better? Is their status as the wealthiest even a reliable reflection of their actual accomplishments in the technological sphere, much less in the social arenas where their venture philanthropy now invades? Consider Microsoft. The company's impressive profits (circa 4.5 billion in 2010) are still primarily dependent on its Windows franchise, whose quality as an operating system has long been attacked by technophiles. 
Wherever one stands on that issue, it is clear that the company has missed almost every significant development in the field since early nineties, failing to be either first or best, for example, with the web browser, the search engine, and the digital music player. Its current clumsy entry into the newest "new things" on the digital scene, cloud computing and social networking, may yet lead to a decline in market share. Irrespective of that outcome, any thorough evaluation of Microsoft's performance would have to conclude that, under Gates's formal and informal leadership, the company has thrived financially not due to its ongoing prophetic excellence but its longstanding monopoly status.

For similar reasons, the BMGF's performance as an effective agent of social betterment has been mixed at best. Here, as Dr. Kochi's complaint suggests, there may even be weaknesses in those fields, like disease prevention, that are susceptible to what Robin Roger's calls "evidence-based solutions." But on the more socially complex subject of education reform, there is no such ambiguity: rarely has so much influence been granted to an institution whose actual track record has been so dismal. From 2000-2008 the BMGF poured up to 2 billion dollars into its small schools project. The plan created over 2600 new schools in 45 states across the nation, with the expectation that these smaller "learning communities" would rapidly boost test achievement. And yet they did not - at which point, undeterred by the enormity of the failure, Gates announced a second initiative, the turnaround agenda, pursuing it with same aggressive zeal as the first.

The allure of the entrepreneur as social prophet has been fueled by his supposed mastery of those elusive numbers that our scientific studies relentlessly produce, but while Gates's reforms are based on his interpretations of research data, the quality of those readings is frequently suspect. There was, in fact, little credible evidence to support his enormous investment in the small-schools project. (The statistician Howard Wainer of the Wharton School suspects that Gates misinterpreted statistical studies of school performance (Golden 2010)). Now, in the light of his first project's failure, Gates has reversed course in some respects. Great teachers, he has decided make the most difference, and his new solution is to add six students to the best teachers' classrooms, using the money saved to increase those teachers' salaries. It is an arrangement, he insisted, citing BMGFsupported research in his latest speech to the nation's governors, that the teachers themselves would gladly support. Here, too, however, his grasp of the numbers has proven shaky. Some fact-checking by the Seattle Times discovered that what the study in question actually found is that teachers would prefer a $\$ 5,000$ raise to having two fewer students - they were never asked about accepting more (Westneat 2011).
Nor does the undiminished support for charter schools by the Gates, Broad, Walton alliance have a sound basis in the data. A 2010 analysis of Milwaukee's Parental Choice Program, the longest-lived and most extensive charter school and voucher program in the nation, found no significant difference in achievement growth rates between pupils in the choice program and those in public schools. ${ }^{2}$ A 2009 study of charter schools in 16 states, conducted by Stanford's Center for Research on Educational Outcomes, asserted that, in the aggregate, charter school students were faring worse (New Stanford Report Finds Serious Quality Challenge in Nation s Charter Schools http credo stanford edu reports National_Release). And although 2010 was the year that Duncan's Ren10 revival of the Chicago's public schools was supposed to prove its worth, an extensive investigation by the Chicago Tribune, "Daley School Plan Fails to Make the Grade," found otherwise.

What proves disturbing here is not that experiments have been tried but the scope and pace of their institution, the rush to nationalize reforms that have either yet to be proven or have even been shown to be largely ineffective. Denying reality is not the hallmark of an entrepreneur committed to "evidence-based solutions"; it is the sign of an ideologue who is cushioned from consequences by money, connections, and public acclaim. It does not seem to matter that Gates keeps misinterpreting the data or that his programs keep failing to "make the grade." Under the turnaround agenda, which is now our national policy, the staffs of struggling schools will continue to be fired while the philanthrocapitalist whose own reforms have failed will, nevertheless, continue to dictate the direction of change. To paraphrase F. Scott Fitzgerald, today's plutocrats are not like you and I; nor do they resemble the politicians we elect. Even when they assume the authority to set public policies, they are, I fear, not sackable.

\section{Cultural Contradictions}

\section{In changing moon, in tidal wave, Glows the feud of Want and Have. \\ Emerson}

Market-based capitalism can be enormously creative in the material sense, but it is a categorical error to presume, as quantiphilia does, that the techniques for boosting productivity in the corporate world can be successfully transferred to the public arena. Human beings are not "upgradeable" machines; standardized tests can only measure a very narrow slice of intellectual achievement; workers in public education and public health bring a different ratio of motivations to their jobs

\footnotetext{
${ }^{2}$ See Murray (2010)
} 
than those in the private sector; insomuch as it emphasizes top-down expertise over on-the-ground experience and competition over collaboration (it is a race to the top, after all), the Turnaround Challenge is not even attuned to the latest developments in the digital world, where wiki software has been engendering whole new ways of doing business, science and scholarship: for these reasons and others, the current template for reforming the nation's schools is bound to fail, both on its own narrow terms and ones more vital to the health of our democracy.

The education agenda now being imposed by the venture philanthropists led by Gates refuses to acknowledge, much less redress, some other powerful causative factors. As Allan Ornstein has noted in this publication, there is a wealth of data "showing that the most important variable related to student achievement is the child's family background and the second most important factor is the peer group (Ornstein 2010)." I have already mentioned the threats associated with our rapidly growing inequality in income distribution. Framed differently, poverty has a wellknown inverse relationship to academic performance, and the percentage of impoverished American students is nearly double that of any other industrialized country, between $21 \%$ and $25 \%$, by Ornstein's account - a difference which in itself can explain most of the achievement gap between American students and those in Western Europe. Unemployment, broken families, excessive TV and internet consumption, lead and mercury pollution, malnutrition, obesity-induced diabetes, restless mobility (moving from school to school as parents try regain an economic foothold) are other known or likely socio-economic factors associated with low achievement.

Any reform movement truly interested in improving student performance would commit itself to rooting out the sources of these often interrelated social ills. Here, however, is where the cultural contradictions of philanthrocapitalism become most obvious, for even as its proponents insist on a strict accountability in the public sphere, they refuse to review the broader social impact of the economic system that has been providing their own excessive compensation. The efficiencies that commend industrial pollution, the downsizing of the white-collar workforce to boost shareholder value, the evisceration of whole communities as plants and services have been sent overseas: the very ethos of rationalization they now would impose on public schools has been complicit in creating social conditions inimical to student achievement.

Eli Broad announced in 2004 that, due to the "crisis" he spied in public education, America was "in danger of becoming a second-class nation (Richard Lee Colvin)." But given that Broad made his billions in real estate and finance, his reformist zeal might have been more effectively aimed at the private industries that he knew best, which were then in the midst of generating the same spectacular economic collapse whose aftereffects now threaten public education with its greatest crisis in many decades. Performance-based pay may be an interesting concept, but it is apparently not applicable to Wall Street whose financial giants "punished" their upper-level employees with 18.4 billion dollars in bonuses in the same year the federal government was bailing them out. Attending to the health of the Third World poor is surely a commendable mission, but as the Los Angeles Times reported in 2007, the BMGF is also heavily invested in corporations whose industrial pollution in the Niger Delta is harmful to its residents' respiratory health - the same residents the foundation was supplying with vaccinations. Nor was this an isolated instance. The Times report concluded that"the foundation reaps vast financial gains every year from investments that contravene its good works," and this conflict between the aims of its charitable grant (preventing illness) and the actions of its endowment holdings (causing illness) captures the moral incoherence at the core of philanthrocapitalism more generally (Piller 2007) .

As Americans, we have had to live with a core contradiction built into our political economy since the Industrial Revolution: namely, that the wealth-producing engine of corporate capitalism can also generate severe social inequalities that threaten the very basis of democratic governance. Along with regulation, taxation, unionism and religious charities, traditional philanthropy by the very wealthy was one way of easing that contradiction by adding "weight to the lighter scale." Included in that traditional offering was a tacit admission that giving back to the community was a compensation for the collateral injustices produced by the system. Venture philanthropy, however, is a different species. Rather than simply offering a compensation for the systems' flaws, it also demands a conversion to that same system's philosophy. Only if we submit to their ideological authority by accepting their quantiphilia will their funds be forthcoming. As such, these are not acts of material generosity so much as ones of intellectual and managerial hubris. The current leveraged takeover of public education by the moneyed few, as endorsed and enforced by first Bush's and now Obama's federal bureaucracy, brings us a very long way from G.K. Chesterton's claim that "the democratic faith is this: that the most terribly important things must be left to ordinary men themselves.... (Chesterton et al. 1990)" We should not delude ourselves that the competence of the plutocrat warrants this surrender of our ordinary authority. On the subject of education, Bill Gates is not even close to being the smartest-man-in-the-room; he is merely the wealthiest and the most willful - someone far more adept at monopolizing power than creating social value.

Ever the optimist, Emerson had faith in "the deep remedial force that underlies all facts": that "the varieties of conditions" do, in the end,"tend to equalize themselves." In the social sphere, however, that process of compensation can assume many forms, some far more desirable than others. There is a 
growing "feud between Want and Have" in the world today, fueled by excessive discrepancies in wealth and power. And as the "tidal wave" of revolutionary change now sweeping across the Middle East ought to remind us, the surest route to "becoming a second-class nation" is to allow a self-selected few to dominate the governance of the many.

\section{References}

Chesterton, G. K. 1990. Orthodoxy: The Romance of Faith. Doubleday, p. 47.

Colvin, R. L. 2005. A New generation of philanthropists and their great ambitions" in With the Best of Intentions, p. 27.

Doughton, S. \& Heim, K. 2011. Does Gates funding of media taint objectivity? Seattle Times.

Golden, D. 2010. Bill Gates School Crusade," Bloomberg Businessweek.

Hess, F. M. (ed). 2005. With the Best of Intentions: How Philanthropy Is Reshaping K-12 Schools. Harvard Eduation Press, p. 9.
Klonsky, M. 2011. Power Philanthropy. In The Gates Foundation and the Future of Public Schools. Routledge, p. 26.

McNeil Jr D. G. 2008. Gates foundation influence criticized. New York Times.

Murray, C. 2010. Why charter schools fail the test. New York Times.

"New Stanford Report Finds Serious Quality Challenge in Nation's Charter Schools": http://credo.stanford.edu/reports/ National_Release.pdf

Ornstein, A. 2010. Achievement Gaps in Education. Society.

Piller, C., Sanders, E., \& Dixon, R. 2007. Dark clouds over good works of Gates Foundation. Los Angeles Times.

Weil, S. 1963. Gravity and Grace. Routledge, p. 151.

Westneat, D. 2011. Bill Gates, have I got a deal for you! Seattle Times.

David Bosworth is the author of two prize-winning books of fiction and numerous essays on cultural change in America. He was a senior consulting scholar for the Thrift Project, a million-dollar multidisciplinary study directed by the Institute for Advanced Cultural Studies, and currently teaches in the University of Washington's Creative Writing Program, where he was Director for five years. All quotes by Emerson are from his essay "Compensation." 